\title{
Shock And Volatility Transmissions Between Bank Stock Returns In Romania: Evidence From A VAR-GARCH Approach
}

Maria Ulici, Babes-Bolyai University, Romania

Anissa Chaibi, IPAG Business School, France

Christophe Rault, Toulouse Business School, France

\begin{abstract}
We develop a VAR-GARCH approach to investigate shock and volatility transmissions between bank stock returns in Romania during the 2007-2009 international financial crisis. Our findings provide evidence of significant shock and volatility transmissions between Romanian bank returns. We also show how our empirical results can be used to build effective diversification and hedging strategies.
\end{abstract}

Keyword: Shock and Volatility Transmission; Financial Crisis; Romanian Banks

\section{INTRODUCTION}

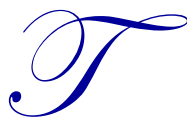

he last global economic and financial crisis was qualified by analysts as the worst crisis since the Great Depression of the 30's, both developed and developing countries were strongly affected. The effects are felt worldwide, generating adjustments both for economic growth and companies' income estimates. In particular, developing countries are confronted with an accelerated reduction in the economic growth and labor force, negative impact on the commercial balance sheet and balance of payments, severe drop of private net capital flows and direct external investments, reduced access to loans and trade financing, exchange rate fluctuations, reserve meltdown, increased volatility, and price decrease for basic products. Several studies have discussed the effects of this crisis on developed and major Asian, European, and Latin-American emerging economies (Kato, 2000; Fernandez-Izquierdo \& Lafuente, 2004; Schwebach et al., 2002; Jara et al., 2009; Chang \& Velasco, 2001). Nevertheless, less mature economies in Eastern Europe, such as Romania, have received very few attention (Dragota \& Mitrica, 2004; Beirne, 2010; Christiansen \& Ranaldo, 2009).

As a developing country, Romania was largely impacted by the crisis. In 2009, the economic growth was interrupted for the first time since 2000: the economic activity decreased by 7.2 percent; the consumer price index increased by 4.74 percent (2009), remaining above the upper limit of the variation interval around the 3.5 percent target set by the National Bank of Romania (NBR); the national currency depreciated compared to the euro by 6.1 percent, in nominal terms. However, according to many economists the highest risks came from the banking sector. Actually, the Romanian banking system entered the crisis well capitalized and with high liquidity buffers, but deteriorating macroeconomic and financial market conditions posed significant risks to financial stability. That is, Romanian banks are included in the medium risk Group D by Moody's. ${ }^{1}$ The years following the current crisis were difficult for the Romanian banks, because of high level commissions to third parties for the non-performing credits and a lower profit rate, although fears regarding liquidity and capital needs have tempered to some extent.

The profitability indicators of the Romanian banking system have decreased significantly: the return on equity ratio dropped from 17 percent (2008) to 3.3 percent (2009), while the return on assets ratio fall from 1.6 percent (2008) to 0.3 percent (2009). Also, the factors influencing the evolution of the banking system, such as nonperforming loans or lending capacity, continued to worsen and put pressure on the results of the banking system

${ }^{1}$ The Moody`s scale goes from A to E, where E represents the maximum risk. 
due to the current crisis (the nonperforming loans to total loans ratio increased from 6.5 percent (2008) to 15.3 percent (2009), while the provisions to nonperforming loans ratio decreased from 60.3 percent (2008) to 47.9 percent (2009)). The NBR has reacted to help banks face the crisis by reducing the minimum reserve requirements applicable to the liabilities in lei of the credit institutions from 18 percent to 15 percent, while the level of the minimum reserve requirements for liabilities in foreign currency with maturities of under two years are from 40 percent to 25 percent and for those with residual maturity of over two years are from 40 percent to zero. Also, the Central Bank has reduced the reference interest five times from 10.25 percent to 8 percent. In May 2010, the level of the NBR reference interest was 6.25 percent. All these elements highlight the interest of studying the systemic risk through investigating shock and volatility transmissions between Romanian banks around the current international financial crisis.

Before 1989, the Romanian banking system was structured in the specific way of a centralized economy. Since 1990, the Romanian Banking System has been a two-tier system, made up of the NBR and credit institutions. Yet, the Romanian banking system is different from banking systems in most developed and emerging countries in several points. First, it is highly concentrated on few private banks. Indeed, the total assets of the Romanian banking system rose during the period 2004 - 2008 with an annual average rate of 34 percent, from RON 133 bn to RON 424 bn, while the net profit registered an increase of 23 percent from RON 3.2 bn to RON 7.2 bn. However, more than 50 percent of credit institutions assets are concentrated on few private banks (Romanian Commercial Bank, Romanian Bank for Development, Volksbank, and Alpha Bank). Second, banks in Romania are largely held by foreign commercial banks, making the Romanian banking system subject to international and contagion effects which may increase the probability of systemic risk. Indeed, in 2009 commercial banks from few countries held the biggest part of the Romanian banking market: Greece (30.7 percent), Austria (23.5 percent), Netherlands (11.9 percent), Italy (6.5 percent), Hungary (6 percent), and France (5.9 percent). Finally, the market capitalization of the Romanian banks listed on Bucharest Stock Exchange (BSE) is very low compared to the banks listed on other stock exchanges.

The Romanian banking system has only four banks listed on BSE: Banca Transilvania (TLV, 1994), Romanian Bank for Development (BRD, 2001), Carpatica Commercial Bank (BCC, 2004), and Erste Group Bank AG (EBS, 2008). ${ }^{2}$ TLV is the 8th bank by total assets with a market share of 5.9 percent (2009), BRD is the second with a market share of 14.1 percent, while BCC is a small bank with a market share estimated at about 1 percent. The first two banks hold a share of 19.94 percent and 20.16 percent of the BET index respectively. Société Générale holds a stake of 58.32 percent of BRD share capital since 2004. As shown in Table 1, the volume of total assets increased during $2004-2008$ at an annual average rate of 43 percent (TLV), 50 percent (BRD), and 52 percent (BCC); while the net profit registered an increase of 30 percent (TLV), 60 percent (BRD), but a decrease for BCC with a positive net profit over this period. The current crisis affected the results of the banks: the net profit decreases from 2008 to 2009 by 42 percent for TLV, 84 percent for BRD, while BCC registered a loss of RON $21 \mathrm{mn}$. This period has equally shown important share price correlations, suggesting significant spillover effects. Indeed, the price share of the banks dropped significantly from their historical maximum (73 percent (TLV), 55 percent (BRD), and 81 percent (BCC)).

Table 1: The Evolution of Banks during 2004-2009

\begin{tabular}{|c|c|c|c|c|c|c|}
\hline & 2004 & 2005 & 2006 & 2007 & 2008 & 2009 \\
\hline \multicolumn{7}{|c|}{ Total Assets (mn. RON) } \\
\hline TLV & $11,665.86$ & $19,221.29$ & $28,026.22$ & $38,965.78$ & $49,239.62$ & $46,346.27$ \\
\hline BRD & $2,603.96$ & $4,932.14$ & $8,085.87$ & $13,876.01$ & $17,014.30$ & $19,472.27$ \\
\hline $\mathrm{BCC}$ & 441.81 & 924.61 & $1,637.31$ & $2,288.74$ & $2,287.70$ & $3,600.84$ \\
\hline \multicolumn{7}{|c|}{ Net Profit (mn. RON) } \\
\hline TLV & 359.68 & 553.24 & 655.58 & 916.91 & 1353.48 & 779.07 \\
\hline BRD & 60.83 & 99.70 & 120.21 & 339.97 & 396.85 & 61.94 \\
\hline $\mathrm{BCC}$ & 13.25 & 17.81 & 19.29 & 8.42 & 0.80 & -21.14 \\
\hline
\end{tabular}

Source: www.bvb.ro

The main purpose of this article is to investigate shock and volatility spillover effects between the main listed Romanian banks (BRD, TLV, and BCC) around the current international financial crisis. Very few studies

\footnotetext{
${ }^{2}$ Our empirical study does not cover EBS as it was introduced in BSE only in February 2008.
} 
have focused on the Romanian stock market (Todea, 2002; Dragota \& Mitrica, 2004), and to our knowledge, none has studied the spillover effects between Romanian banks. More interestingly, we make use of VAR-GARCH models recently introduced by Ling and McAller (2003). One of the main advantages of this approach is that it allows us to investigate the conditional returns and volatility dynamics of each bank as well as the conditional shock and volatility transmissions between the three banks. It also provides meaningful estimates of the parameters with less computational complication than several other multivariate specifications, such as the full factor GARCH model. Furthermore, we are able to use our findings to compute the optimal weights of Romanian banks portfolios as well as optimal hedge ratios to analyze hedging effectiveness. At the best of our knowledge, this modelling framework has never been employed to study the volatility transmission between banks.

As for shock and volatility transmission, early studies of spillovers across national stock markets primarily covered advanced countries. Prompted by the October 1987 stock market crash in the US, Hamao et al. (1990), King and Wadhwani (1990), and Schwert (1990) examined spillovers across major markets before and after the crash. Recently, there have been scores of new research papers mostly focusing on identifying spillovers of return and volatility shocks among emerging stock markets based on aggregated national indices. Singh et al. (2010) study mean and volatility spillovers among 15 countries from North American, European, and Asian stock markets. They use VAR and GARCH models and found that there is a greater regional influence among Asian and European stock markets. Applying multivariate volatility models (MVGARCH), Johansson et al. (2009) investigate the possible volatility spillover effects to shed light on the dynamic relationships among the three markets in the Greater China region and found short-run spillover effects in both return and volatility in the region. Yilmaz (2010) proposes a new approach to the analysis of contagion and interdependence across the East Asian equity markets over the 1992-2009 period and compares the ongoing crisis with earlier episodes. He shows that volatility and return spillovers behave very different over time, during crisis and non-crisis episodes.

Christiansen et al. (2009) investigate the integration and contagion effects in new European Union (EU) member states`stock markets and found a closer connection of new EU stock markets to those in Western Europe, respectively that the flip side of the financial market integration is stronger cross-country shock propagation. Beirne et al. (2010) study global and regional spillovers in 41 local emerging stock markets using a tri-variate VAR and GARCH $(1,1)$-in-Mean models. Their results suggest that spillovers from regional and global markets are present in vast majority of emerging stock markets. In regards to Romania, this study shows that spillovers in variance appear to play a key role. At individual firm level, Todea (2002) and Dragota and Mitrica (2004) focus on the informational efficiency on the Romanian stock market using standard methods (correlation, linear regressions, etc.). Results of Todea (2002) are not against the weak-form efficiency hypothesis, while Dragota and Mitrica (2004) reject the efficiency hypothesis. However, at the best of our knowledge, there are no previous works on spillover effects within the Romanian market at firm level.

The remaining part of the paper is structured as follows. Section 2 introduces the recent empirical methodology we use to investigate shock and volatility spillovers between Romanian banks. Section 3 presents the data, discusses the empirical results and shows their implications for portfolio management. Concluding remarks are summarized in Section 4.

\section{METHODOLOGY}

To study the volatility of stock returns, GARCH-type models have been used by almost all previous papers. Moreover, it is commonly shown that multivariate GARCH models such as BEKK (full parameterization), CCC (constant conditional correlation), or DCC (dynamic conditional correlation) models with dynamic covariance and conditional correlation are more appropriate than univariate models. These models, however, are extremely difficult to estimate, especially when a great number of variables are considered. More importantly, they do not explicitly allow for cross-market volatility spillover effects. That is, we make use of the recently developed VAR-GARCH model to explore the volatility transmission between the main Romanian banks during last years. Introduced by Ling and McAleer (2003), this approach was applied to stock markets and tourism demand variation by, among others, Chan et al. (2005), Hammoudeh et al. (2009), and Chang et al. (2010) and appears to provide meaningful and interpretable coefficients. Precisely, the VAR-GARCH model of Ling and McAleer (2003) includes the multivariate CCC-GARCH model of Bollerslev (1990) as a special case in which correlations of system shocks are assumed to 
be constant to ease the estimation and inference procedure. In this paper, we adopt the trivariate form of this model. The specification we consider is thus a trivariate $\operatorname{VAR}(1)-\operatorname{GARCH}(1,1)$ in which the conditional mean is given by: ${ }^{3}$

$$
\begin{aligned}
& r_{t}^{T L V}=a_{T L V}+b_{T L V} r_{t-1}^{T L V}+c_{T L V} r_{t-1}^{B R D}+d_{T L V} r_{t-1}^{B C C}+e_{T L V} D 07+\varepsilon_{t}^{T L V} \\
& r_{t}^{B R D}=a_{B R D}+b_{B R D} r_{t-1}^{T L V}+c_{B R D} r_{t-1}^{B R D}+d_{B R D} r_{t-1}^{B C C}+e_{B R D} D 07+\varepsilon_{t}^{B R D} \\
& r_{t}^{B C C}=a_{B C C}+b_{B C C} r_{t-1}^{T L V}+c_{B C C} r_{t-1}^{B R D}+d_{B C C} r_{t-1}^{B C C}+e_{B C C} D 07+\varepsilon_{t}^{B C C}
\end{aligned}
$$

where

$-\quad Y_{t}=\left(r_{t}^{T L V}, r_{t}^{B R D}, r_{t}^{B C C}\right)^{\prime}$ and $r_{t}^{T L V}, r_{t}^{B R D}$, and $r_{t}^{B C C}$ are the returns at time $t$ on TLV, BRD and BCC respectively;

- $\quad D 07$ is a dummy that takes the value 1 after August $1^{\text {st }}, 2007$;

- $\quad \varepsilon_{t}=D_{t} \eta_{t}$ with $\varepsilon_{t}=\left(\varepsilon_{t}^{T L V}, \varepsilon_{t}^{B R D}, \varepsilon_{t}^{B C C}\right)^{\prime}$ and $\varepsilon_{t}^{T L V}, \varepsilon_{t}^{B R D}$, and $\varepsilon_{t}^{B C C}$ are the residual terms from the mean equations of the three bank stock returns respectively;

- $\quad \eta_{t}=\left(\eta_{t}^{T L V}, \eta_{t}^{B R D}, \eta_{t}^{B C C}\right)^{\prime}$ refers to a (3×1) vector of independently and identically distributed errors;

- $\quad$ and $D_{t}=\operatorname{diag}\left(\sqrt{h_{t}^{T L V}}, \sqrt{h_{t}^{B R D}}, \sqrt{h_{t}^{B C C}}\right)$ and $h_{t}^{T L V}, h_{t}^{B R D}$, and $h_{t}^{B C C}$ are the conditional variances of $r_{t}^{T L V}, r_{t}^{B R D}$ and $r_{t}^{B C C}$ respectively, given by:

$$
\begin{aligned}
h_{t}^{T L V}= & C_{T L V}^{2}+\beta_{T L V, 1}^{2} h_{t-1}^{T L V}+\alpha_{T L V, 1}^{2}\left(\varepsilon_{t-1}^{T L V}\right)^{2}+\beta_{B R D, 1}^{2} h_{t-1}^{B R D}+\alpha_{B R D, 1}^{2}\left(\varepsilon_{t-1}^{B R D}\right)^{2} \\
& +\beta_{B C C, 1}^{2} h_{t-1}^{B C C}+\alpha_{B C C, 1}^{2}\left(\varepsilon_{t-1}^{B C C}\right)^{2}+\gamma_{T L V} D 07
\end{aligned}
$$

$$
\begin{aligned}
h_{t}^{B R D}= & C_{B R D}^{2}+\beta_{T L V, 2}^{2} h_{t-1}^{T L V}+\alpha_{T L V, 2}^{2}\left(\varepsilon_{t-1}^{T L V}\right)^{2}+\beta_{B R D, 2}^{2} h_{t-1}^{B R D}+\alpha_{B R D, 2}^{2}\left(\varepsilon_{t-1}^{B R D}\right)^{2} \\
& +\beta_{B C C, 2}^{2} h_{t-1}^{B C C}+\alpha_{B C C, 2}^{2}\left(\varepsilon_{t-1}^{B C C}\right)^{2}+\gamma_{B R D} D 07 \\
h_{t}^{B C C}= & C_{B C C}^{2}+\beta_{T L V, 3}^{2} h_{t-1}^{T L V}+\alpha_{T L V, 3}^{2}\left(\varepsilon_{t-1}^{T L V}\right)^{2}+\beta_{B R D, 3}^{2} h_{t-1}^{B R D}+\alpha_{B R D, 3}^{2}\left(\varepsilon_{t-1}^{B R D}\right)^{2} \\
& +\beta_{B C C, 3}^{2} h_{t-1}^{B C C}+\alpha_{B C C, 3}^{2}\left(\varepsilon_{t-1}^{B C C}\right)^{2}+\gamma_{B C C} D 07
\end{aligned}
$$

As can be seen, the conditional bank returns depend on both their past values and the past values of other bank returns. Moreover, the introduction of the dummy variable D07 allows us testing for the effects of the international 2007-2009 crisis on bank returns. Similarly, the conditional variance of each bank returns depends not only on its own past values and innovations but also on those of the other bank returns. This particular feature permits the direct transmission of volatility and shocks from one bank to another. We also test for the effects of the crisis on bank return volatilities by the means of $D 07$. Finally, we can also express the conditional covariance, $h_{t}^{i j}$, as follows:

$$
h_{t}^{i j}=\rho_{i j} \sqrt{h_{t}^{i}} \sqrt{h_{t}^{j}}
$$

\footnotetext{
${ }^{3}$ The optimal number of lags for the VAR system was chosen on the basis of commonly-used information criteria.
} 
where $i, j=T L V, B R D$, and $B C C$ and $\rho_{i j}$ is the conditional constant correlation between $\mathrm{i}$ and $\mathrm{j} .{ }^{4}$

Taken together, the features of the proposed model allow us to capture both return and volatility spillover effects between the Romanian banks we study. To the extent that the normality condition is often rejected for the majority of macroeconomic and financial series, we use the quasi-maximum likelihood (QML) method to estimate the parameters of the model. ${ }^{5}$

\section{DATA AND EMPIRICAL RESULTS}

In this section, we first present the data and some preliminary results. Then, we discuss our empirical findings and present some portfolio implications of our main outcomes.

\subsection{Data and Preliminary Analysis}

As we explained above, no more than 4 banks are listed on BSE, the fourth one (EBS) was introduced in BSE only in February 2008. Therefore, we choose to investigate spillover effects among the 3 banks for which we have data for the longest period: TLV, BRD, and BCC. We make use of daily close prices during the period from August 8, 2005 to September 12, 2008. Data of these assets have been taken from the Bursa Noastra site ${ }^{6}$ using the MetaStock program. We have to stop our analysis in September 2008 because TLV was suspended from trading during September 12, 2008 to January 6, 2009 (the bank change the nominal value of their share).

Table 2 reports the main descriptive statistics for return series. Average returns are positive for two banks (TLV and BRD) and negative for BCC. BRD has the highest volatility followed by BCC. There is also strong evidence of ARCH effects for all series and there are significant serial correlations for BCC. Finally, Skewness is negative and Kurtosis is above 3. Thus, the Jarque-Bera test statistic (JB) strongly rejects the hypothesis of normality in all cases.

Table 2: Descriptive Statistics

\begin{tabular}{|c|c|c|c|}
\hline \multicolumn{4}{|c|}{ Panel A: Basic Statistics } \\
\hline & TLV & BRD & BCC \\
\hline Mean & 0.020 & 0.046 & -0.057 \\
\hline Maximum & 6.216 & 11.627 & 13.976 \\
\hline Minimum & -8.456 & -10.531 & -15.349 \\
\hline Std. Dev. & 1.667 & 2.205 & 2.002 \\
\hline Skewness & -0.237 & -0.016 & -0.170 \\
\hline Kurtosis & 5.249 & 6.515 & 14.285 \\
\hline Jarque-Bera & $178.162 *$ & $416.455^{*}$ & $4296.382 *$ \\
\hline$Q(6)$ & 7.330 & 2.290 & $31.660 *$ \\
\hline $\operatorname{ARCH}(6)$ & $86.373 *$ & $38.665 *$ & $136.496 *$ \\
\hline \multicolumn{4}{|c|}{ Panel B: Unconditional Correlations } \\
\hline & TLV & BRD & BCC \\
\hline TLV & 1.000 & & \\
\hline BRD & 0.533 & 1.000 & \\
\hline BCC & 0.395 & 0.377 & 1.000 \\
\hline
\end{tabular}

We also compute in Panel B the unconditional correlations between bank stock returns. They range from 0.38 (between BRD and BCC) to 0.53 (between BRD and TLV). These correlations are not too high, suggesting benefits from portfolio diversification within Romanian banks.

\footnotetext{
${ }^{4}$ It is worth emphasizing that the model VAR-GARCH with dynamic conditional correlations has not yet been analysed theoretically (McAleer et al., 2009; Chang et al., 2010).

${ }_{6}^{5}$ See Ling and McAleer (2003) for further details about the asymptotic properties of the VAR-GARCH model and its estimation procedure.

${ }^{6}$ www.bursanoastra.ro
} 
Figure 1 plots the evolution of stock prices, returns, and volatilities. Returns are computed using the logarithm differences of stock prices, while volatilities are estimated using simple GARCH $(1,1)$ models. Visual inspection of the graphs suggests that prices have sharply decreased during the international 2007-2009 crisis for the three banks. Moreover, stock returns seem to be more volatile. Finally, as it can be observed, we visualize some signs of volatility clustering (i.e., alternatives between periods of high return instability and periods of stability) and persistence (i.e., return volatility tends to remain in the same regime for a long time span).

\section{Panel A: Stock Prices}
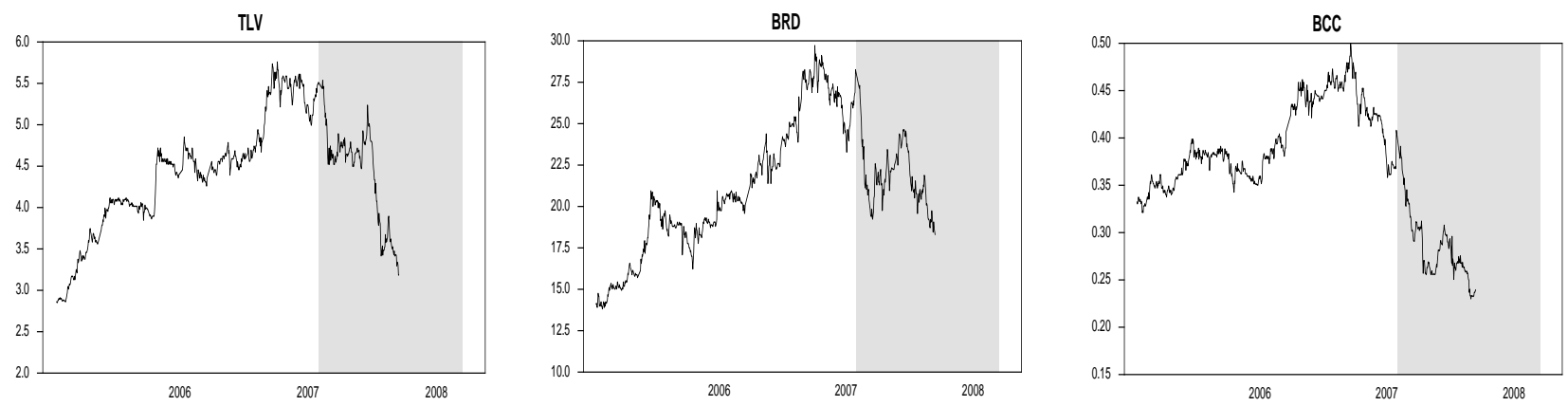

Panel B: Stock Returns
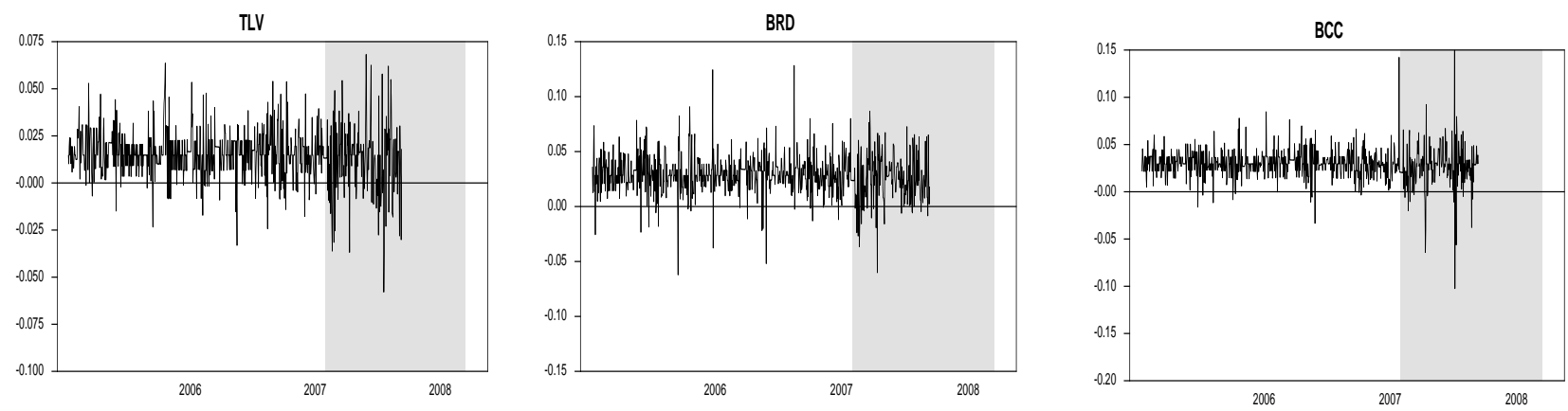

Panel C: Stock Volatilities
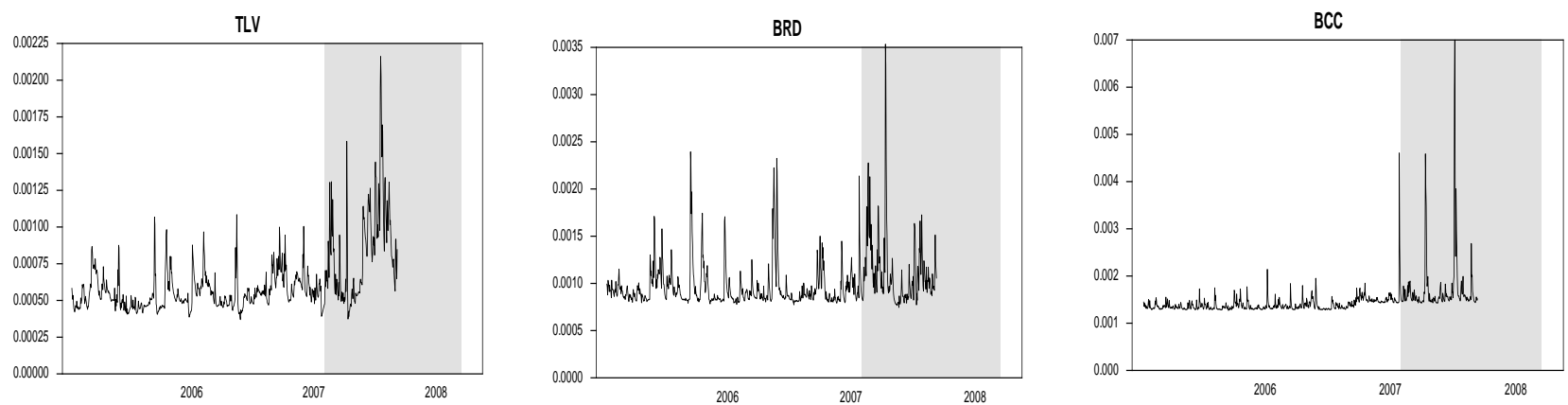

Figure 1: Dynamics of Prices, Return, and Volatilities

To empirically assess the impact of the international 2007-2009 financial crisis on Romanian bank returns and volatilities, we test for structural breaks based of our dummy variable which takes the value one during the crisis and zero before. More precisely, we estimate the simple following model: 
$\delta_{t}=\alpha+\beta D 07+\varepsilon_{t}$

where $\delta_{t}$ is first the bank return and then the bank volatility.

Table 3: Effects of the Crisis on the Analyzed Romanian Banks

\begin{tabular}{ccccccc}
\hline & \multicolumn{3}{c}{ Returns } & \multicolumn{3}{c}{ Volatilities } \\
\hline$\alpha$ & TLV & BRD & BCC & TLV & BRD & BCC \\
& $0.173^{* *}$ & $0.174^{* * *}$ & 0.088 & $2.017^{*}$ & $4.408^{*}$ & $2.480^{*}$ \\
$\beta$ & $(0.072)$ & $(0.096)$ & $(0.087)$ & $(0.100)$ & $(0.138)$ & $(0.179)$ \\
& $-0.424^{*}$ & $-0.354^{* *}$ & $-0.400^{*}$ & $2.420^{*}$ & $1.298^{*}$ & $3.390^{*}$ \\
& 0.121 & $(0.160)$ & $(0.145)$ & $(0.167)$ & $(0.229)$ & $(0.298)$ \\
\hline
\end{tabular}

Notes: ${ }^{* * *},{ }^{*}$ and ${ }^{* * *}$ denote rejection of the null hypothesis at the 1 percent, 5 percent, and 10 percent respectively.

Results of structural break tests are reported in Table 3. As expected, for returns the coefficient $\beta$ is negative for the three banks. This result corroborates the conclusion that the international crisis has negatively affected bank returns in Romania. However for volatilities, the coefficient $\beta$ is significantly positive indicating that during the crisis bank returns were more volatile.

\subsection{Empirical Results}

Our VAR(1)-GARCH(1,1) estimation results are shown in Table $4 .^{7}$ The current returns for TLV significantly depend on past BRD returns, while past returns of TLV significantly affect the current returns on BRD. Returns of BCC are affected by their own past values and by past returns on BRD. Overall, our results suggest some predictability in the Romanian banks based on previous returns. This result confirms those of Dragota and Mitrica (2004) and suggests that the weak-form informational efficiency of the Romanian market is rejected. More importantly, our findings confirm our previous results (Table 3) and show that the crisis has decreased bank returns in Romania and there are significant return transmissions between banks.

The estimates of ARCH and GARCH coefficients in the conditional variance equations are significant at conventional levels in most cases. Sensitivity to past own conditional volatility (GARCH-term) appears to be significant for all series at the 1 percent level. Our estimation results suggest also that the current conditional volatility of stock returns in Romanian banks depends as well on past shocks affecting return dynamics, since ARCH-terms are highly significant for all series. Moreover, the ARCH coefficients are relatively small in size, which indicates that conditional volatility does not change very rapidly. However, the GARCH coefficients are large, indicating gradual fluctuations over time.

Table 4: Estimation Results

\begin{tabular}{|c|c|c|c|}
\hline \multicolumn{4}{|c|}{ Panel A: Mean Equation Estimates } \\
\hline & TLV & BRD & BCC \\
\hline \multirow[t]{2}{*}{$\mathbf{C}$} & 0.112 & $0.089 * * *$ & 0.059 \\
\hline & $(0.099)$ & $(0.053)$ & $(0.061)$ \\
\hline \multirow{2}{*}{$r_{t-1}^{T L V}$} & -0.023 & $0.194 *$ & 0.063 \\
\hline & $(0.034)$ & $(0.040)$ & $(0.043)$ \\
\hline \multirow{2}{*}{$r_{t-1}^{B R D}$} & $0.080^{*}$ & 0.001 & $-0.125 *$ \\
\hline & $(0.014)$ & $(0.039)$ & $(0.043)$ \\
\hline \multirow{2}{*}{$r_{t-1}^{B C C}$} & 0.006 & -0.031 & $0.098^{*}$ \\
\hline & $(0.023)$ & $(0.0380)$ & $(0.031)$ \\
\hline \multirow{2}{*}{$D 07$} & $-0.162 * * *$ & $-0.055 * * *$ & $-0.141 *$ \\
\hline & $(0.096)$ & $(0.031)$ & $(0.052)$ \\
\hline
\end{tabular}

\footnotetext{
${ }^{7}$ The lags were selected conformed to multivariate AIC and BIC criteria.
} 
Table 4 cont.

\begin{tabular}{|c|c|c|c|}
\hline \multicolumn{4}{|c|}{ Panel B: Variance Equation Estimates } \\
\hline & TLV & BRD & BCC \\
\hline \multirow[t]{2}{*}{$\mathbf{C}$} & $0.173^{*}$ & $0.199 * *$ & $0.182 *$ \\
\hline & $(0.035)$ & $(0.043)$ & $(0.037)$ \\
\hline \multirow{2}{*}{$\left(\varepsilon_{t-1}^{T L V}\right)^{2}$} & $0.130 *$ & 0.067 & -0.080 \\
\hline & $(0.024)$ & $(0.047)$ & $(0.053)$ \\
\hline \multirow{2}{*}{$\left(\varepsilon_{t-1}^{B R D}\right)^{2}$} & $0.078^{*}$ & $0.146^{*}$ & $0.014 * *$ \\
\hline & $(0.017)$ & $(0.032)$ & $(0.007)$ \\
\hline \multirow{2}{*}{$\left(\varepsilon_{t-1}^{B C C}\right)^{2}$} & $0.053 * *$ & $0.160 *$ & $0.255^{*}$ \\
\hline & $(0.025)$ & $(0.044)$ & $(0.041)$ \\
\hline \multirow[t]{2}{*}{$h_{t-1}^{T L V}$} & $0.140 *$ & -0.023 & 0.209 \\
\hline & $(0.057)$ & $(0.167)$ & $(0.226)$ \\
\hline \multirow[t]{2}{*}{$h_{t-1}^{B R D}$} & $-0.042 *$ & $0.645^{*}$ & 0.031 \\
\hline & $(0.013)$ & $(0.053)$ & $(0.351)$ \\
\hline \multirow{2}{*}{$h_{t-1}^{B C C}$} & -0.133 & -0.129 & $0.368 *$ \\
\hline & $(0.164)$ & $(0.214)$ & $(0.106)$ \\
\hline \multirow{2}{*}{$D 07$} & $0.204 * * *$ & 0.080 & $0.871^{*}$ \\
\hline & $(0.113)$ & $(0.163)$ & $(0.210)$ \\
\hline \multicolumn{4}{|c|}{ Panel C: Constant Conditional Correlation Estimates } \\
\hline & TLV & BRD & BCC \\
\hline TLV & 1.000 & & \\
\hline \multirow[t]{2}{*}{ BRD } & $0.500 *$ & 1.000 & \\
\hline & $(0.025)$ & & \\
\hline $\mathbf{B C C}$ & $0.351 *$ & $0.357 *$ & 1.000 \\
\hline Log likelihood & $\frac{(0.032)}{6568.565}$ & $(0.055)$ & \\
\hline AIC & -16.162 & & \\
\hline
\end{tabular}

Next, we discuss our findings regarding the volatility transmission between Romanian bank returns. Previous shocks on BRD and BCC significantly affect the volatility of the three banks, while previous shocks on TLV do not affect the other bank returns. Past volatility of BRD stock returns significantly affect the current volatility of TLV. Furthermore, our findings suggest that the intensity of volatility spillover varies according to the bank importance. Thus, to better forecast bank return volatility in Romania and make appropriate investment decisions, investors should keep a close watch on what is going on with other listed banks and on how shocks affecting a bank are transmitted.

Finally, as expected the estimates for the constant conditional correlations between the three banks are close to the unconditional correlations reported in Table 2. Moreover, they are not too high, suggesting the existence of potential gains from building a portfolio of Romanian banks. However, the significant returns and volatility spillover we show in this paper requires portfolio managers to quantify the optimal weights and hedging ratios to deal properly with systematic risk in Romania. In what follows, we will analyze the optimal weights and hedge ratios for Romanian bank portfolio holdings.

\subsection{Portfolio Management with Bank-Risk Hedging Strategies}

To investigate some of the portfolio implications of our results, we consider a portfolio of Romanian bank stocks which minimizes risk without reducing expected returns. According to Kroner and $\mathrm{Ng}$ (1998), the optimal weight of holdings in a portfolio of two assets (bank 1 and bank 2) is given by:

$$
w_{12, t}=\frac{h_{t}^{1}-h_{t}^{12}}{h_{t}^{1}-2 h_{t}^{12}+h_{t}^{2}}
$$

and, 


$$
w_{12, t}=\left\{\begin{array}{l}
0, \text { if } \quad w_{12, t}<0 \\
w_{12, t}, \quad \text { if } \quad 0 \leq w_{12, t} \leq 1 \\
1, \text { if } \quad w_{12, t}>1
\end{array}\right.
$$

where $w_{12, t}$ refers to the weight of bank 1 in a one-dollar two-asset portfolio at time $t ; h_{t}^{1}, h_{t}^{2}$, and $h_{t}^{12}$ the conditional variance of bank 1 , variance of bank 2 , and covariance of bank 1 and bank 2 , respectively. Therefore, the optimal weight of bank 2 in the considered portfolio is $1-w_{12, t}$.

Table 5: Weights and Hedge Ratios

\begin{tabular}{lcc}
\hline & $w_{\text {os }, t}$ & $\beta_{\text {os }, t}$ \\
\hline TLV/BRD & 0.740 & 0.379 \\
TLV/BCC & 0.602 & 0.314 \\
BRD/BCC & 0.377 & 0.441 \\
\hline Notes: The table shows average optimal weights and hedge ratios in a two-bank portfolio. &
\end{tabular}

The average values of $w_{12, t}$ (optimal weights) for the three couples are shown in Table 5. They vary from 38 percent for the couple (BRD/BCC) to 74 percent for the couple (TLV/BRD). This suggests that for an investor who wants to invest in stocks of BRD and BCC, the optimal holding of stocks of BRD in a one-dollar BRD-BCC portfolio should be 38 percent, with the remainder of 62 percent invested in the stocks of BCC. For the couple (TLV/BRD), these optimal investment weights are 74 percent and 26 percent, while for the couple (TLV/BCC) the investor should invest 60 percent in TLV and 40 percent in BCC.

As for hedge ratios, Kroner and Suktan (1993) consider a portfolio of two assets (bank 1 and bank 2 in our case). To minimize the risk of this portfolio, a long position of one dollar in bank 1 should be hedged by a short position of $\beta_{t}$ dollars in bank 2 , that is:

$$
\beta_{12, t}=\frac{h_{t}^{12}}{h_{t}^{2}}
$$

Table 5 shows average values of the hedge ratios computed by using Equation (10) over the estimation period. As we can see, these ratios are low; suggesting that hedging involving banks in Romania has high effectiveness. Accordingly, one Romanian Leu (RON) long in TLV should be shorted by about 38 bani and 31 bani of stocks in BRD and BCC respectively. ${ }^{8}$ Our results are thus consistent with the view that diversifying within Romanian bank stocks increases the risk-adjusted performance of the resulting portfolio.

\section{CONCLUSION}

This paper added to the literature on systematic risk in economies in transition by investigating the mean and volatility transmission between the main banks in Romania around the 2007-2009 international financial crisis. To that goal, we made use of the recent VAR-GARCH approach introduced by Ling and McAleer (2003), which allows for spillover effects in both conditional returns and volatilities. We also analyzed the optimal weights and hedge ratios for portfolio holdings.

Overall, our findings point to the existence of significant shock and volatility spillovers between banks in Romania, with the transmission more apparent from large bank to small banks. Moreover, we show that the international crisis has had negative effects on bank stock returns in Romania and increased their volatilities. Our

${ }^{8} 1$ Leu $=100$ Bani. 
findings suggest also that diversifying within Romanian banks improves the overall risk-adjusted performance of the formed portfolio and that it makes it possible to hedge bank risk more effectively.

\section{AUTHOR INFORMATION}

Maria Ulici, FEBA, Babes-Bolyai University, Romania. E-mail: maria.ulici@econ.ubbcluj.ro

Anissa Chaibi, IPAG Business School, Paris, France. E-mail: anissa.chaibi@ipag.fr (Corresponding author)

Christophe Rault, Toulouse Business School, France. E-mail: chrault@ hotmail.com

\section{REFERENCES}

1. Beirne, J., Caporale, G. M., Schulze-Ghattas, M., \& Spagnolo, N. (2010). Global and regional spillovers in emerging stock markets: A multivariate GARCH-in-mean analysis, Emerging Markets Review.

2. Bollerslev, T. (1990). Modelling the coherence in short-run nominal exchange rates: Amultivariate generalized ARCH approach, Review of Economics and Statistics, 72, 498-505.

3. Chan, F., Lim, C., \& McAleer, M. (2005), Modelling multivariate international tourism demand and volatility. Tourism Management, 26, 459-471

4. Chang, C. L., Khamkaew, T., McAleer, M., \& Tansuchat, R. (2010). Interdependence of international tourism demand and volatility in leading ASEAN destinations. (Working Paper). Center for International Research on the Japanese Economy (CIRJE).

5. Chang, R., \& Velasco, R. (2001). A model of financial crises in emerging markets. The Quarterly Journal of Economics, 116(2), 489-517.

6. Christiansen, C., \& Ranaldo, A. (2009). Extreme coexceedances in new EU member states' stock markets. Journal of Banking \& Finance, 33(6), 1048-1057.

7. Dragota, V., \& Mitrica, E. (2004). Emergent capital markets`efficiency: The case of Romania. European Journal of Operational Research, 155, 353-360.

8. Driga, I., \& Guta, A. J. (2009). Romanian bank lending during the financial crisis. Young Economists Journal, 12, 22-27.

9. Fernandez-Izquierdo, A., \& Lafuente, J.A. (2004). International transmission of stock exchange volatility: Empirical evidence from the Asian crisis. Global Finance Journal, 15, 125-137.

10. Hamao, Y., Masulis, R. W., \& Ng, V. (1990). Correlations in price changes and volatility across international stock markets. The Review of Financial Studies, 3(2), 281-307.

11. Hammoudeh, S., Yuan, Y., \& McAller, M. (2009). Stock and volatility spillovers among equity sectors of the Gulf Arab stock markets. The Quarterly Review of Economics and Finance, 49, 829-842.

12. Hassan, H., \& Malik, F. (2007). Multivariate GARCH model of sector volatility transmission. The Quarterly Review of Economics and Finance, 47, 470-480.

13. Ilie, A. G., Colibasanu, O. A., Sarbu, R., \& Dumitriu, D. (2009). The core of a new type of crisis: Subprime crisis. The Romanian Economic Journal, XII(32), 47-68.

14. Isarescu, M. (2008). Romania in the context of the global financial crisis. Conference organized by the National Bank of Romania, Bucharest, 10 December 2008.

15. Jara, A., Moreno, R., \& Tovar, C. E. (2009). The global crisis and Latin America: Financial impact and and policy responses. BIS Quarterly Review, 53-68.

16. Johansson, A. C., \& Ljungwall, C. (2009). Spillover effects among the greater China stock markets. World Development, 37(4), 839-851.

17. Kato, T. (2000). Lessons from the Asian crisis. Journal of Human Development and Capabilities, 1(1), 165-168.

18. King, M. A., \& Wadhwani, S. W. (1990). Transmission of volatility between stock markets. Review of Financial Studies, 3, 5-33.

19. Kroner, K. F., \& Ng, V. K. (1998). Modeling asymmetric movements of asset prices. Review of Financial Studies, 11, 844-871.

20. Kroner, K. F., \& Sultan, J. (1993). Time dynamic varying distributions and dynamic hedging with foreign currency futures. Journal of Financial and Quantitative Analysis, 28, 535-551. 
21. Ling, S., \& McAleer, M. (2003). Asymptotic theory for a vector ARMA-GARCH model. Econometric Theory, 19, 278-308.

22. McAleer, M., Hoti, S., \& Chan, F. (2009). Structure and asymptotic theory for multivariate asymmetric conditional volatility. Econometric Reviews, 28(5), 422-440.

23. Schwebacha, R. G., Olienyka, J. P., \& Kenton Zumwalt, J. K. (2002). The impact of financial crises on international diversification. Global Finance Journal, 13, 147-161.

24. Schwert, G. W. (1990). Stock returns and real activity: A century of evidence. Journal of Finance, American Finance Association, 45(4), 1237-57.

25. Singh, P., Kumar, B., \& Pandey, A. (2010). Price and volatility spillovers across North American, European and Asian stock markets. International Review of Financial Analysis, 19, 55-64.

26. Todea, A. (2002). Teoria pieţelor eficiente şi analiza tehnică: cazul pietei romanesti. Studia Universitatis Babeş-Bolyai, Oeconomica, Cluj-Napoca, XLVI(1), 107-117.

27. Yilmaz, K. (2010). Return and volatility spillovers among the East Asian equity markets. Journal of Asian Economics, 21, 304-313. 


\section{NOTES}

